\title{
Korelasi PBBH dengan Perubahan Ukuran Linear Tubuh pada Ternak Kambing Kacang Betina Lokal yang Diberikan Kombinasi Hijauan
}

\author{
Aloysia Febronia Lake ${ }^{\mathrm{a}}$ \\ ${ }^{a}$ Fakultas Pertanian, Universitas Timor, Kefamenanu, TTU - NTT, 85613, Indonesia.
}

\section{Article Info}

\section{Article history:}

Received 12 Januari 2016

Received in revised form 2 Februari 2016

Accepted 15 Maret 2016

Keywords :

Kambing Kacang

PBBH

Ukuran Linear

\begin{abstract}
Abstrak
Penelitian ini bertujuan untuk mengetahui nilai korelasi antara pertambahan bobot badan harian (PBBH) dengan perubahan ukuran linear tubuh ternak kambing betina lokal yang diberi kombinasi hijauan berupa rumput alam, lamtoro dan turi. Penelitian ini menggunakan 16 ekor ternak kambing yang berumur 6-9 bulan dengan berat badan awal $10 \mathrm{~kg}-21 \mathrm{~kg}$. Rancangan yang digunakan adalah rancangan acak kelompok (RAK) dengan empat perlakuan dan empat ulangan. Perlakuan tersebut adalah $\mathrm{r}_{0}$ (100\% rumput alam), $\mathrm{r}_{1}$ (40\% rumput alam, $30 \%$ lamtoro, 30\% turi), $\mathrm{r}_{2}$ (30\% rumput alam, 35\% lamtoro, 35\% turi) dan $\mathrm{r}_{3}$ (20\% rumput alam, $40 \%$ lamtoro, $40 \%$ turi). Hasil penelitian menunjukkan bahwa besaran nilai korelasi antara PBBH dengan perubahan lingkar dada yakni 0,163774, panjang badan 0,9889526, tinggi pundak 0,35564, sehingga disimpulkan bahwa terdapat hubungan yang positif antara PBBH dan perubahan ukuran linear tubuh ternak (lingkar dada, panjang badan, tinggi pundak). (02016 dipublikasikan oleh JAS.
\end{abstract}

\section{Pendahuluan}

Sektor pertanian, khususnya sektor peternakan merupakan salah satu bagian dari sumber daya alam yang perlu dikelola semaksimal mungkin dan diharapkan dapat mendukung pembangunan masyarakat. Melalui nilai gizi dari produk peternakan yang dihasilkan, seperti daging, susu dan telur akan berdampak pada peningkatan sumber daya manusia yang sehat, handal, cerdas, berkualitas dan produktif. Salah satu komoditi penghasil daging yang potensial dan produktif berasal dari ternak kambing.

Ternak kambing merupakan ternak ruminansia kecil yang mudah dalam pemeliharaannya serta modal yang dibutuhkan sedikit dan resiko kerugiannya kecil bila dibandingkan dengan ternak ruminansia besar. Ternak kambing juga mempunyai peranan yang cukup penting dalam rangka memenuhi kebutuhan protein hewani bagi masyarakat. Namun demikian usaha ternak kambing pada umumnya masing-masing dilakukan petani peternak sebagai usaha sampingan atau tambahan untuk memenuhi kebutuhan keluarga dengan pemeliharaan yang masih sederhana atau tradisional.

Makanan pokok bagi ternak ruminansia adalah hijauan yang terdiri dari rumput alam dan leguminosa. Rumput merupakan pakan dasar ternak kambing yang banyak digunakan oleh masyarakat petani peternak diwilayah Nusa Tenggara Timur (NTT). Nilai nutrisi rumput lapangan dianggap rendah selain itu sifatnya sangat fluktuasi seiring dengan perubahan musim. Selain rumpu lapangan, terdapat sumber bahan makanan lain yang biasanya digunakan sebagai pakan ternak seperti lamtoro (Leucaenan leucocephala) dan turi (Sesbania grandiflora). Ketiga jenis makanan ini banyak dijumpai hampir di seluruh wilayah NTT.

Daun lamtoro, turi dan rumput lapangan merupakan sumber protein bahan makanan yang potensial dan juga memiliki nilai kecernaan yang tinggi. Pemanfaatan daun lamtoro, turi dan rumput lapangan sebagai pakan ternak oleh petani peternak di pedesaan merupakan suatu solusi menuju pola pemeliharaan ternak kambing secara intensif sehingga sangat menunjang usaha ternak kambing karena jumlahnya yang berlimpah.

Manajemen pakan merupakan salah satu faktor penentu dalam keberhasilan usaha penggemukan karena penerapan manajemen pakan yang tepat akan sangat berpengaruh terhadap tercapainya produktifitas ternak secara maksimal. Salah satu ukuran produktifitas adalah melalui penilaian terhadap linear tubuh ternak hal ini sesuai dengan pendapat Gunawan (1998) yang menyatakan bahwa ukuran linear tubuh adalah ukuran bagian tertentu yang dapat digunakan sebagai acuan untuk mengetahui pertumbuhan atau pertambahan berat badan harian pada ternak.

Korelasi merupakan teknik analisis yang termasuk dalam salah satu teknik pengukuran asosiasi/hubungan (measures of association). Pengukuran asosias merupakan istilah umum yang mengacu pada sekelompok teknik dalam statistik bivariat yang digunakan untuk mengukur kekuatan hubungan antara dua variable. Ukuran linier tubuh dapat dijadikan dasar untuk menafsir bobot badan ternak. Ukuran linier tubuh memiliki korelasi yang positif dengan bobot badan (Obeth, 1989).

Penelitian ini bertujuan untuk mengetahui nilai korelasi antara pertambahan bobot badan harian $(\mathrm{PBBH})$ dengan perubahan ukuran linear tubuh ternak kambing betina lokal yang diberi kombinasi hijauan berupa rumput alam, lamtoro dan turi.

\section{Metode}

Penelitian dilaksanakan di Desa Inbate, Kecamatan Bikomi Nilulat, Kabupaten Timur Tengah Utara (TTU). Penelitian dilakukan selama sembilan minggu (63 hari) termasuk persiapan dan pelaksanaan.

Rancangan yang digunakan dalam penelitian ini adalah rancangan acak kelompok (RAK) sebagai rancangan lingkungannya dan terdiri dari empat perlakuan dan empat ulangan sehingga terdapat 16 unit satuan percobaan. Adapun perlakuan yang diuji adalah $\mathrm{r}_{0}\left(100 \%\right.$ rumput alam), $\mathrm{r}_{1}(40 \%$ rumput alam, $30 \%$ lamtoro, $30 \%$ turi), $\mathrm{r}_{2}$ (30\% rumput alam, $35 \%$ lamtoro, $35 \%$ turi) dan $r_{3}$ (20\% rumput alam, $40 \%$ lamtoro, $40 \%$ turi).
Penelitian diawali dengan survey lokasi untuk meninjau sejauh mana potensi yang dimiliki di sekitar lokasi penelitian serta kaidah-kaidah yang dapat diatasi sebelum penelitian dimulai beserta konsultasi dengan pemilik ternak. Yang termasuk disini adalah ternak percobaan serta alat-alat dan bahan-bahan yang mendukung terlaksananya penelitian harus memadai. Pembangunan kandang juga termasuk rangkaian kegiatan yang terlebih dahulu dipersiapkan sesuai dengan jumlah ternak percobaan. Alat dan bahan yang dipakai dalam pembuatan kandang ini disediakan disekitar lokasi penelitian.

Periode penyesuaian atau preliminary merupakan tahap dimana ternak percobaan harus memperoleh perlakuan ransum sebelum memasuki periode pertama. Periode penyesuaian ini diaplikasikan selama kurun waktu satu minggu, dengan tujuan menyesuaikan ternak terhadap pakan lingkungan serta menghilangkan efek dan pakan sebelumnya.

Ternak yang digunakan sebanyak 12 ekor dengan masing-masing perlakuan sebanyak empat ekor. Selanjutnya dilakukan penimbangan bobot badan harian awal serta pengukuran linear tubuh (lingkar dada, panjang badan dan tinggi pundak) awal. Setelah ukuran tubuh awal diketahui selanjutnya melakukan pengacakan ternak terhadap kandang serta ransum perlakuan. Satu minggu sebelum preliminary dan awal periode sepanjang periode pengambilan data, pakan sudah disediakan. Ransum dapat diberikan kepada ternak $\pm 10 \%$ per hari serta pemberian air secara ad libitum setiap hari. Sebelum diberikan ransum tersebut ditimbang sesuai dengan kebutuhannya. Sisa dari hasil pakan yang tidak dikonsumsi selama 24 jam juga ditimbang untuk mengetahui tingkat konsumsi. Sebagai variabel yang diteliti dalam penelitian ini, pengukuran linear tubuh (lingkar dada, panjang badan dan tinggi pundak) diukur setiap minggu. Untuk menjamin kesehatan ternak, diadakan pembersihan kandang setiap hari.

Variabel yang di ukur dalam penelitian ini adalah 1) Korelasi bobot badan dengan lingkar dada; 2) Korelasi bobot badan dengan panjang badan dan 3 ) Korelasi bobot badan dengan tinggi pundak.

Analisis data dilakukan dengan menggunakan korelasi pearson product moment (PPM) atau disebut korelasi pearson. Analisis data dilakukan sesuai petunjuk Irianto (2010)

\section{Hasil dan Pembahasan}

3.1 Korelasi PBBH dengan Lingkar Dada

Kecepatan pertumbuhan adalah karakteristik penting dalam usaha ternak Menurut Dwiyanto et al. (1982), dalam proses pertumbuhan ternak kambing, pertumbuhan kerangka diperioritaskan kemudian baru pertumbuhan daging dan pada akhirnya terjadi penimbunan lemak.

Hasil analisis menunjukkan nilai korelasi (r) sebesar 0,163774 yang berarti adanya hubungan yang positif antara pertambahan bobot badan harian dengan pertambahan ukuran linear tubuh ternak. Artinya setiap peningkatan lingkar dada sebesar $0,44 \mathrm{~cm}$ per minggu maka diikuti pula pertambahan bobot badan sebesar $0,57 \mathrm{~g}$ per minggu.

Pertambahan ukuran lingkar dada dipengaruhi oleh dua aspek yaitu perubahan ukuran tulang, dalam hal ini rusuk dada dan perubahan ukuran atau penimbunan lemak dan daging dalam tubuh (jaringan otot). Pada ternak yang bertumbuh mengalami pertambahan berat badan akan semakin meningkat, sehingga ternak tersebut memiliki perototan yang baik dan secara langsung mempengaruhi konformasi tubuh. Kondisi ini dipahami bahwa dengan makin bertambah pula ukuran lingkar dada (Anggorodi, 1994). Pertambahan ukuran lingkar dada akan diikuti oleh perubahan ukuran lebar dan panjang kulit (luas kulit), sehingga pada bobot badan yang berbeda akan berbeda pula ukuran berat dan luas kulitnya. Data yang diperoleh pada penelitian ini sejalan dengan pendapat Dwiyanto et al. (1982) bahwa komponen tubuh yang mempunyai hubungan paling erat dengan bobot hidup adalah lingkar dada.

\subsection{Korelasi PBBH dengan Panjang Badan}

Hasil analisis menunjukkan nilai korelasi (r) sebesar 0,989526 yang berarti adanya hubungan yang positif dan kuat antara panjang badan dengan rata-rata pertambahan bobot badan harian ternak. Artinya setiap peningkatan panjang badan sebesar $0,44 \mathrm{~cm}$ per minggu maka diikuti pula pertambahan bobot badan 
sebesar 0,57 g per minggu. Hal ini sejalan dengan Frandson (1992) yang menyatakan bahwa kerangka yang disusun dari beberapa jenis tulang memberikan dasar pada struktur eksternal dan wujud ternak. Scanes (2003) juga menyatakan perbedaan ukuran tubuh pada saat dewasa kelamin dapat memberikan penampakan yang berbeda setiap ternak walaupun ternak-ternak tersebut berada dalam satu areal kandang penelitian.

Kecepatan pertumbuhan pada ternak Kambing Kacang betina lokal dipengaruhi oleh kebutuhan pakan dengan proporsi tinggi dan pengelolaan yang baik sebagaimana pendapat Parakasi (1999) bahwa faktor pakan sangat penting dalam pemenuhan kebutuhan pertumbuhan, kekurangan pakan merupakan suatu kendala besar dalam proses pertumbuhan. Lebih parah lagi dalam pakan tersebut tidak banyak memiliki zat-zat yang diperlukan untuk pertumbuhan seperti vitamin, protein dan lemak.

3.3 Korelasi PBBH dengan Tinggi Pundak

Hasil analisis menunjukkan nilai $r$ sebesar 0,035 yang berarti adanya hubungan positif antara tinggi pundak ternak dengan rata-rata pertambahan bobot badan harian ternak. Artinya setiap peningkatan tinggi pundak sebesar $0,30 \mathrm{~cm}$ per minggu maka diikuti pula pertambahan bobot badan sebesar $0,57 \mathrm{~g}$ per minggu.

Faktor yang diduga mempengaruhi kecepatan pertambahan ukuran tinggi pundak ternak adalah pada sifat fisiologi ternak sehubungan dengan tumbuh kembang ternak status produksinya, dimana fase awal kecepatan pertumbuhan pada pembentukan struktur tulang, menyusul pembentukan struktur otot dan berakhir pada pembentukan deposit lemak.

Hal ini sesuai dengan pendapat Anggorodi (1994) bahwa pertumbuhan mempunyai tahap yang cepat (terjadi sampai pubertas) dan tahap lambat (jika dewasa tubuh telah tercapai), dan tulang paling cepat pertumbuhannya disusul otot dan lemak paling lambat berhenti pertumbuhannya.

Secara keseluruhan pertumbuhan dibagi dalam dua periode yaitu periode pertumbuhan prenatal dan postnatal. Pada periode postnatal biasanya mulai perlahan-lahan, pertumbuhan yang cepat terjadi pada saat hewan masih muda atau belum mencapai dewasa kelamin, dan bila mencapai dewasa kelamin pertumbuhan akan menurun sampai pada saat tidak terjadinya pertumbuhan atau berhenti sama sekali. Pertumbuhan tubuh dan organ-organ tersebut akan tumbuh dan mengalami pembesaran sejalan dengan pertumbuhan ternak.

Menurut Murtidjo (1995) makanan diperlukan untuk memproduksi jaringan tubuh dan meningkatkan berat tubuh. Faktor pakan sangat penting dalam pemenuhan kebutuhan pertumbuhan, sehingga dengan demikian kekurangan pakan merupakan kendala besar dalam proses pertumbuhan.

\section{Simpulan}

Terdapat hubungan yang positif antara perubahan ukuran linear tubuh ternak (lingkar dada, panjang badan, tinggi pundak) dengan pertambahan bobot badan harian ternak kambing kacang betina yang diberi kombinasi hijauan berupa rumput alam, lamtoro dan turi. Peningkatan bobot badan sebesar $0,57 \mathrm{~g}$ per minggu maka peningkatan lingkar dadanya sebesar $0,44 \mathrm{~cm}$ per minggu, panjang badannya sebesar $0,44 \mathrm{~cm}$ per minggu dan tinggi pundaknya sebesar $0,30 \mathrm{~cm}$ per minggu dengan nilai korelasi antara $\mathrm{PBBH}$ dengan perubahan lingkar dada, panjang badan, tinggi pundak, berturut-turut adalah sebesar 0,16 ; 0,98 dan 0,03 .

\section{Pustaka}

Anggorodi, R. 1994. Ilmu Makanan Ternak Umum. Penerbit PT. Gramedia, Jakarta.

Dwiyanto, K,. H. Martojo dan Siswadi.1982. Pengamatan ukuran permukaan Tubuh Domba di Kapupaten Garut Serta Hubungan Dengan Bobot Badan. Procceding Pertemuan Ilmiah Penelitian Rumunansia Kecil. Bogor

Frandson, R. D. 1992. Anatomi dan Fisiologi Ternak. Terjemahan: Srigandono dan K. Praseno. Edisi Keempat. Gajah Mada University Press: Yogyakarta.

Gunawan, 1998. Ukuran Linier Tubuh, Sebagai Acuan Untuk Mengetahui Pertumbuhan Atau Pertambahan Berat Badan Ternak. Tarsito: Bandung

Irianto A. 2010. Statistika Konsep, Dasar, Aplikasi, dan Pengembangannya. Kencana Prenada Media Group. Jakarta.

Murtidjo B. A. 2005. Memelihara Kambing Sebagai Ternak Potong dan Perah. Penerbit Kanisius, Yogyakarta.

Obeth, I. 1989. Korelasi Antara Ukuran Linear Tubuh Dengan Bobot Badan Pada Kambing Lokal Di Kecamatan Amarasi Kabupaten Kupang. Penerbit Fakultas Peternakan Undana Kupang (Tidak Di Publikasikan), Kupang.

Parakasi, A., 1999. Ilmu Nutrisi dan Makanan Ternak. Universitas Indonesia, Jakarta.

Scanes, C. G. 2003. Biology of Growth of Domestic Animals. $1^{\text {St }}$. Edition. Iowa State Press, Iowa. 